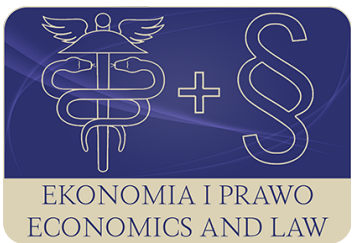

EKONOMIA I PRAWO. ECONOMICS AND LAW

Volume 16, Issue 4, December 2017

p-ISSN 1898-2255, e-ISSN 2392-1625

www.economicsandlaw.pl

ORIGINAL ARTICLE

received 13.06.2017; revised 01.12.2017; accepted 31.12.2017

Citation: Gałecka, M., \& Smolny, K. (2017). Financing rules of the activity of cultural institutions in the context of economic efficiency. Ekonomia i Prawo. Ecomomics and Law, 16(4): 387-399.

\title{
Financing rules of the activity of cultural institutions in the context of economic efficiency
}

\section{MAEGORZATA GAEECKA}

corresponding author

Wroclaw University of Economics, Faculty of Economic Sciences, Department of Finance, ul. Komandorska 118/120, 53-345 Wroclaw, Poland

$\square$ malgorzata.galecka@ue.wroc.pl

KATARZYNA SMOLNY

Wroclaw University of Economics, Faculty of Economic Sciences, Department of Finance, Poland $\square$ katarzyna.smolny@ue.wroc.pl

\begin{abstract}
Motivation: The authors are interested in the problem of financing of theatres as cultural institutions also because of the arising conflict between the objectives set by the organizers of the institutions, and those managers and artists consider the most important in the public cultural institutions.

Aim: The aim of this article is the efficiency evaluation of statutory subsidies granted to cultural institutions in the context of subsidizing rules of these institutions.

Results: The system of financing municipal cultural institutions is predominantly based on statutory subsidies from the organizer's budget. Therefore, statutory grants play an important role of creating income and of stabilizing finances of cultural institutions. Their share in the total amount of revenue of the examined cultural institutions persisted at a high level throughout subsequent years of the study period. Although statutory subsidies significantly improve the financial situation of cultural institutions. Those which are using subsidies to a lesser degree, and those whose important source of financing their activities were their own revenues, are characterized by higher efficiency. Unfortunately, the analysis of the data indicates that there is a very small group of institutions characterized by a high indicator of financing.
\end{abstract}


Keywords: economic efficiency; public expenditures; cultural institutions; performing art organizations; financing rules; subsidies

JEL: H2; H7; G18

\section{Introduction}

Cultural institutions in Poland fulfil through their activities the constitutional role of the state, consisting in providing access to culture for all citizens. Considering the importance of this assignment, methods that would prove successful in efficient management of cultural institutions should be unceasingly sought.

The concept of 'culture' is one of the toughest and most capacious concepts. The eighteenth-century philosopher J. G. Herder (1964, p. 4) summarized already that: 'there is nothing more indeterminate than the word culture'. Owing to the fact that culture has long been a problem of public funding, more precise attributes, that cultural activity should be characterised by, have appeared as well. David Throsby mentions three basic characteristics of cultural activities: they require creativity, they generate and transmit a symbolic meaning and their results are covered by intellectual property rights (Thorsby, 2000, p. 4). The debate over the concept of culture (Strent, 2011, p. 133) does not fall within the abovementioned topic, however, the concept of economics of culture is appearing increasingly in the realm of finance (Ilczuk, 2011, p. 7).

Theatres alongside concert halls, operas and operettas are an important group of facilities of culture-production nature. Although they can offer the society so-called culture consisting of being so close to the performance of an actor, to an instrument, a costume, the number of these institutions in Poland is successively decreasing over last several years, and it has not been changed by the fact that since 3-4 years the downward trend has been slightly reversed (chart. 1). The data clearly show a decrease in the amount of these facilities, what might suggested a problem with the functioning of these institutions. More than $80 \%$ of theatres in Poland are financed by subsidy from the budget of a local government unit or from the state budget. A higher level of subsidy than theatres show museums, libraries and cultural centres (Głowacki et al., 2009, p. 44).

The aim of this article is the efficiency evaluation of statutory subsidies granted to cultural institutions (CI) in the context of subsidizing rules. The authors make the argument that subsidized CI in Poland report heterogeneous financial results despite the fact that their financial management is based on the same financing rules.

The authors assume that similar amounts of transfers should provide a comparable range of performed tasks, and thus the access to goods and services supplied. From the point of view of economic efficiency of public expenditure, it can be assumed that in case of CI, the result of the outlay (it means of the organiser's statutory subsidies) is (indirectly), among others the level of own funds produced by these institutions. 


\section{Literature review}

The analysis of the public expenditure efficiency is not any new problem in the literature. Significance, amount and range of financing particular benefits from public funds is a persisting dilemma not only of scientists and of the circles interested themselves, but also of the socio-political debate. As already P. Samuelson (1954, pp. 387-389) was the author of the theory of public goods, disposer of those is the collective consumer. Also the universal accessibility justifies government intervention regarding financing culture because culture, no matter what its demand is, is a socially acceptable good due to positive externalities (merit goods) (Baumol \& Bowen, 1966, p. 582). The importance of culture as a prerequisite for sustainable development has been emphasized many times, what also justifies the subsidizing of CI (Thorsby, 2000, p. 31). P. Bendixen (2001, p. 13), looking for links and relations between market-driven economies and culture, concluded that modern economies could not develop without the contribution of culture. At the same time he emphasized that, due to the specific nature of $\mathrm{CI}$ and their social mission, it was extremely difficult to determine the boundary between effective spending of money for cultural activities and wasting of them (Bendixen, 2001, p. 11). Costs and thereby the financial result were also analysed in terms of technological progress, what differently from production influences creators of culture.

On the basis of century-old observation of such performances, a theory evolved called 'cost disease' (Baumol \& Bowen, 1966, p. 542), which is the reason for permanent deficits affecting cultural production. The cost disease results also from the demand for cultural goods and thereby from the price that consumers are able to pay for the use of these goods. Due to that, in the literature, the subsidizing of cultural activities has long been justified, and John Maynard Keynes himself got involved in building of public support for CI (Ilczuk, 2015, p. 6). The theory of cost disease has often been positively verified, among others by the abovementioned Thorsby (2000, p. 23).

Although the literature generally considers the subsidizing of cultural activities justified, again and again a need for further development of tools and guidelines to evaluate activities of $\mathrm{CI}$ and thereby to determine the efficiency of public expenditure is arising (see: Thorsby, 2010, p. 44).

The authors also point out the possibility of implementation in CI controlling tools used in companies (Wnuczak, 2014, p. 6). Such controlling instruments include, among others, widely understood reporting systems, cost accounting, and budgeting. Budgeting as an element of managing CI appears also in Byrnes' (2008, pp. 284-297) publications, who emphasizes the great importance of creating budgets for them. The authors carrying out this study will focus exactly on economic efficiency, ignoring other aspects of efficiency.

According to the art. $27 \$ 1$ Act on organizing (AO) a cultural institution manages independently the given and acquired part of assets and it runs its own independent economy within the possessed resources, it has a legal personality 
and is independently responsible for its liabilities. Under the art. 4 paragraph 1 section Public Finance Act (PFA) and AO state and local CI are counted as entities of the public finance sector, which by their activity perform the constitutional role of the state, consisting in providing access to culture for all citizens (Lewandowski, 2006, p. 3).

A lack of homogenous rules for obtaining ministerial subsidies as well as statutory ones by local CI casts a shadow on the constitutional principle of adequacy, which should be applied to those institutions. The multidimensionality of obtaining subsidies is at odds with the principle of financial self-management. This principle allows self-managing assigned assets and the self-management as regards given resources. The main limitation of the principle of self-management, apart from subsidies, is the principle of efficiency, which will be pointed out by the authors during the course of the elaboration.

On the basis of PFA the principle of direct budget financing cultural activities of the institutions whose statutes include objectives or tasks related to cultural activities can be articulated. An addition to this principle is the principle of indirect financing cultural activities through a system of earmarked subsidies and specific grants Art 9 point $2 \mathrm{AO}$. It is worth mentioning that PFA is mainly dedicated to specific grants, what corresponds to the abovementioned inconsistency in the existing of the principle of adequacy, and at the same time of the idea of self-governance and decentralization (Szlendak et al., 2012, p. 35). This principle is often articulated as financing of CI by the organizer in the form of various types of subsidies.

PFA clearly articulates the principle of public expenditure with the use of the public procurement law - Art $44 \$ 4$. The most important concept associated with such orders is the most advantageous offer or an order with the lowest price. In the case of public procurements in the field of creative or scientific activities, most advantageous is the offer that represents the best balance of price and other criteria relating to the subject of the public procurement (Szlendak et al., 2012, p. 39).

PFA requires that public expenditure is done in a purposeful and cost-effective way, bearing in mind the principle of efficient use of resources Art $44 \mathbb{} 3$ (PFA). The principle of efficient use of resources consists in getting the best results from the investment. It also demands an optimal choice of ways and methods of achieving set objectives, what indicates that it is necessary to choose only offers with the most advantageous balance of price and other criteria relating to the subject of the public procurement.

In conclusion, cultural institutions, according to the art. $27 \$ 1 \mathrm{AO}$, run their own independent economy within the possessed resources, bearing in mind the principles of efficiency of their use. The basis for the financial management is a financial plan established by the director, with reference to the unchanged amount of the organizer's subsidies. The consequence of this principle is the principle of direct financing of CI from the budget. Public expenditure should be done - in a purposeful and cost-effective way, with bearing in mind 
the principles of: obtaining the best results from the investment, optimal choice of ways and methods of achieving set objectives, this principle corresponds to the principle of implementation of public procurement law.

\section{Methods}

The subject of the study of measuring the economic efficiency of the expenditure of $\mathrm{CI}$ are public theatres and music institutions in cities belonging to the category of large cities, i.e. with the population of one hundred thousand to a million. The object of the study was limited to CI whose core business include musical activities consisting in satisfying the needs and cultural inspirations of the society by creating theatre performances and by dissemination of performing arts in the form of operetta performances, shows and musical events or ballet. However, only those institutions whose organizer is a municipality.

The conducted study was to approve or reject the hypothesis according to which the subsidized performing arts organizations (PAO) in Poland have heterogeneous financial results although their financial management are based on the same financing rules. Data for the study was obtained through individual inquiries via Internet concerning reports on implementation of financial plans of municipal PAO for the years 2010-2015.

Cultural institutions can receive both statutory subsidies - dedicated for current operations, and specific grants. For the study, however, only statutory subsidies provided by the organizer will be taken into account.

For the sake of better transparency of data, when the study was conducted, a distribution of features into four compartments, in which the results will be classified, was introduced. These compartments, called quartiles, correspond to the distribution of the data included in the boxplot, which will be used for the presentation and interpretation of the data result. In order to determine the level of variation of costs of particular PAO the coefficient of variation was used.

In turn, the Pearson correlation coefficient allowed to determine whether there is a relationship between the level of statutory subsidy in overall revenue and the financial result expressed in overall costs.

\section{Results}

From a purely economic point of view, the analysis of finances indicates the inefficiency of all institutions. In the majority these are institutions that live on thanks to income from organizer's subsidies, generating low own revenue in relation to the incurred costs.

In order to maintain continuity and development of activities, own revenue, independently generated by a cultural institution, is particularly important. Particularly the share of own revenue in the total revenue should be considered (further below it will be also referred to as an indicator of self-financing). 
This potential for self-financing is a way to preserve the autonomy in the scope of activities performed (Kowalik et al., 2013, p. 76). Moreover, PAO should run its own economy within the possessed resources, based on a financial plan, bearing in mind the principle of efficiency of their use. Therefore, it is important to maintain a balance between generating of revenue and providing of public services by $\mathrm{PAO}$, and the level of subsidies.

The conducted study showed that the substantial majority of PAO is characterized by almost negligible or low share of own revenue in the total revenue. In the majority of the examined $\mathrm{PAO}$ - in 54 cases, which represents more than $90 \%$ - the share of own revenue in total revenue did not exceed the $51 \%$. Therefore, the economic efficiency of these institutions can be described as very low.

The performed analysis indicates that in particular PAO the indicator of self-financing was at the similar level throughout the whole study period. Small increases and decreases occurring in particular years affect only slightly the ability to self-finance (chart 2). The level of own revenue in the majority of PAO did not allow of self-financing.

The result of this study confirmed symmetrically the previously revealed indicator of financing.

The conducted studies proved that statutory subsidies are an important factor of the revenue of PAO. While these institutions generated relatively low own revenue in relation to the total revenue, the share of subsidies in the total revenue is significant (chart 3).

Among the examined theaters there were theatres characterized by an extraordinary low value of the indicator of the share of statutory subsidies in relation to the total revenue'. In the whole study period, four theaters were characterized by a low share of subsidies.

The conducted study indicates a relatively stable level of statutory subsidies granted to the respective PAO in the whole study period. It is visible both in the parameters of the share of statutory subsidies in the total revenue of PAO and in the nominal amount of the subsidies granted to them. The existing variations of the nominal level of the granted subsidies are insignificant and they refer only to isolated cases. The management of a PAO without any motivation of acquiring resources, does not want, or rather does not need to take any additional action. Moreover, it is worth mentioning that there are no tools to measure and evaluate other aspects of the efficiency - social impact, number of premiers, performances, capacity of the auditorium etc. Therefore, a lack of tools to evaluate a level of implementation of statutory objectives, frequently pointed out in the literature, is visible (Lewandowski, 2006, p. 108; Wnuczak, 2014, p. 6).

The authors measured the share of the statutory subsidies provided by the organizer in the costs incurred by these institutions, should be indicated. The value of the resulting indicator will determine, firstly what amount of the cost is financed by public resources. Secondly, whether the level of subsidies varies depending on the incurred total costs (chart 4). 
The conducted studies show that a significant growth of the share of the minimum subsidy in relation to the cost was due to the relatively faster growth of subsidies in relation to changes in the costs. Moreover, this situation confirms that the organizer does not verify the levels of nominal subsidies in relation to other variables. This might be due to a lack of clearly defined internal procedures, functioning at the level of local government, that would determine the criteria for granting the statutory subsidies.

A negative indicator of the financial result to the costs indicates a lack of economic stability of the respective theaters in relation to the homogenous rules of their financing. It should be pointed out that, compared to the costs, the level of the losses was relatively low, fluctuating around a few percent. Most of the PAO justified their negative financial result by a high depreciation (chart5).

There is no relationship between the amount of the statutory subsidies expressed in the total revenue and the financial results expressed in the total costs. The Pearson correlation coefficient for the studied features was 0.0042 .

\section{Conclusion}

The analysis of the data indicates that there is a very small PAO group characterized by a high indicator of financing. Although statutory subsidies significantly improve the financial situation of $\mathrm{PAO}$, those are using subsidies to a lesser degree, and those whose important source of financing their activities were their own revenues, are characterized by higher efficiency. This proves the authors' thesis on heterogeneous financial results and other financing conditions, although all institutions were based on the same financial rules.

Financial independence of PAO, based on sustainability of their financing sources is an essential condition for their harmonious development. A lack of objective criteria for granting subsidies, a lack of yardsticks of efficiency, and of a scheduled level of co-financing does not provide this stability. The level of subsidies depends essentially on the organizer, which causes an increased uncertainty regarding not only the amount to be received, but also payment terms. A lack of internal criteria for distribution of subsidies between various PAO only intensifies the lack of that stability.

From an economic point of view, this situation might be caused by a lack of adequate incentives to increase own revenue due to the organizer's subsidies ensuring at least theoretically, coverage of costs of facility maintenance and, as it results from the analysis, the costs of the activity of theatres. The differences between the relationship of the costs and the revenue showed that for only $25 \%$ of PAO the subsidy did not exceed almost a half of the cost, what indicates that the level of implementation of the principle of efficiency and thriftiness is not applied to the same extent. Similarly - the principle of doing expenditures in an efficient and cost-effective way does not lead to a homogeneous indicator of relationship of the costs and the revenue. 
In conclusion, it should be emphasized that despite homogenous principles of granting statutory subsidies, the economic efficiency of individual PAO of culture is diverse.

The efficiency of public expenditure is affected by more aspects than just economic efficiency - in fact economic efficiency alone is not an indicator sufficient to evaluate the efficiency of expenditure. A lack of correlation between the level of the financial result and the level of statuary subsidies or of the total costs of a PAO leads to conclusion that more factors in this field should be investigated. Probably, level of fixed and variable costs, level of depreciation, repertoire, increase of the costs in relation to the increasing subsidy or nominal decrease of own revenue in relation to the decreasing subsidy and the way of managing, should be analysed.

\section{References}

Baumol, W., \& Bowen, W.G. (1966). Performing arts. The economic dilemma. A study of problems common to theater, opera, music and dance. New York: The Twentieth Century Fund.

Bendixen, P. (2001). Wprowadzenie do ekonomiki kultury i sztuki. Kraków: UJ.

Białystok. (2010-2015). Informacja o przebiegu wykonania planów finansowych samorzadowych instytucji kultury miasta Bialystok. Paper version received from City of Białystok.

Bielsko-Biała. (2010-2015). Sprawozdanie z wykonania budżetu miasta Bielsko-Biata. Paper version received from City of Bielsko-Biała.

Bydgoszcz. (2010-2015). Sprawozdanie roczne z wykonania planu finansowego samorządowych instytucji kultury w Bydgoszczy. Paper version received from City of Bydgoszcz.

Byrnes, W. (2008). Management and the arts. New York: Elsevier. doi:10.1016/ B978-0-240-81004-1.00009-6.

Bytom. (2010-2015). Sprawozdanie $z$ wykonania planów finansowych samorzadowych instytucji kultury miasta Bytom. Paper version received from City of Bytom.

Częstochowa. (2010-2015). Sprawozdanie z wykonania planów finansowych samorzadowych instytucji kultury Częstochowy. Retrieved 27.07.2016 from http://www.czestochowa.pl.

Gdańsk. (2010-2015). Sprawozdanie z wykonania planów finansowych miejskich instytucji kultury miasta Gdańsk. Retrieved 1l.07.2016 from http://bip.gdansk.pl. Gdynia. (2010-2015). Informacja o wykonaniu planu finansowego instytucji kultury Miasta Gdynia. Paper version received from City of Gdynia.

Głowacki, J., Hausner, J., Jakóbik, K., Markiel, K., Mituś, A., \& Żabiński, M. (2009). Finansowanie kultury i zarządzanie instytucjami w kulturze. Kraków: UE w Krakowie, Małopolska Szkoła Administracji Publicznej.

Herder, J. (1964). Myśli o filozofii dziejów. Warszawa: PWN. 
Ilczuk, D. (2011). Ekonomika kultury jako dziedzina badawcza. In D. Ilczuk, \& S. Ratajski (Eds.), Edukacja przez kulturę. Kreatywność i innowacyjność. Warszawa: Polski Komitet ds. UNESCO.

Ilczuk, D. (2015). Ekonomika kultury. Warszawa: PWN.

Katowice. (2010-2015). Sprawozdania z wykonania planów finansowych samorzadowych instytucji kultury Miasta Katowice. Retrieved 15.07.2016 from http://bip.katowice.eu.

Kowalik, W., Malczyk, K., Maźnica, Ł., \& Strycharz, J. (2013). Kompetencje kadr kultury a rozwój kapitału spotecznego. Kraków: Małopolski Instytut Kultur.

Kraków. (2010-2015). Sprawozdanie $z$ wykonania planów finansowych samorządowych instytucji kultury Miasta Kraków. Retrieved 15.07.2016 from https://www.bip.krakow.pl.

Lewandowski, M. (2006). Zmiany w sposobach zarządzania a pomiar efektywności zarządzania w instytucjach kultury. Zarządzanie w Kulturze, 7.

Local Data Bank. (2017). Data on theaters and music institutions (spr. K-01). Retrieved 10.06.2017 from https://bdl.stat.gov.pl.

Lublin. (2010-2015). Sprawozdanie z wykonania planu finansowego samorzadowych instytucji kultury Lublina. Paper version received from City of Lublin.

Łódź. (2010-2015). Informacja o przebiegu wykonania planów finansowych samorzadowych instytucji kultury miasta Łodzi. Paper version received from City of Łódź.

Olsztyn. (2010-2015). Sprawozdanie finansowe z przebiegu wykonania planów finansowych instytucji kultury Olsztyna. Paper version received from City of Olsztyn.

Poznań. (2010-2015). Sprawozdanie z wykonania planów finansowych instytucji kultury miasta Poznania. Paper version received from City of Poznań.

Radom. (2010-2015). Sprawozdanie z realizacji planu finansowego instytucji kultury gminy Radom. Paper version received from City of Radom.

Samuelson, P.A. (1954). The pure theory of public expenditure. The Review of Economics and Statistics, 36(4). doi:10.2307/1925895.

Strent, R. (2011). Kultura - co to pojęcie dla nas znaczy? In D. Ilczuk, \& S. Ratajski (Eds.), Edukacja przez kulturę. Kreatywność i innowacyjność. Warszawa: Polski Komitet ds. UNESCO.

Szczecin. (2010-2015). Sprawozdanie finansowe instytucji kultury miasta Szczecin. Paper version received from City of Szczecin.

Szlendak, T., Nowiński, J., \& Wieczorek, T. (2012). Podręcznik szkoleniowy dotyczący sektora kultury w Polsce dla wnioskodawców i partnerów Programu „Promowanie różnorodności kulturowej $i$ artystycznej $w$ ramach europejskiego dziedzictwa kulturowego" finansowanego z funduszy EOG 2009-2014. Warszawa: MKiDN.

Thorsby, D. (2000). Economics and culture. Cambridge: Cambrigde University Press. doi:10.1017/CBO9781107590106.

Thorsby, D. (2010). The economics of cultural policy. Cambridge: Cambrigde University Press. doi:10.1017/CBO9780511845253. 
Toruń. (2010-2015). Informacja o przebiegu wykonania planu finansowego instytucji kultury miasta Toruń. Paper version received from City of Toruń.

Tychy. (2010-2015). Sprawozdanie z wykonania planów finansowych instytucji kultury miasta Tychy. Retrieved 15.07.2016 from https: / /www.bip.umtychy.pl.

Warszawa. (2010-2015). Informacja z wykonania planów finansowych instytucji kultury Warszawy. Paper version received from City of Warszawa.

Wnuczak, P. (2014). Stosowanie narzędzi controllingu w polskich publicznych instytucjach kultury. Zeszyty Teoretyczne Rachunkowości, 79(135).

Wrocław. (2010-2015). Sprawozdanie roczne z wykonania planu finansowego samorzadowych instytucji kultury Miasta Wroctawia. Paper version received from City of Wroclaw.

\section{Acknowledgements}

Author contributions: authors have given an approval to the final version of the article. Authors contributed to this work equally.

Funding: this research was fully funded by the Wroclaw University of Economics, Faculty of Economic Sciences, Department of Finance statutory sources.

Note: the results of this study were presented at 9th International Conference on Applied Economics Contemporary issues in Economy (June 22-23, Torun, Poland). 


\section{Appendix}

\section{Chart 1.}

Number of theaters and music institutions in Poland between 2005 and 2015

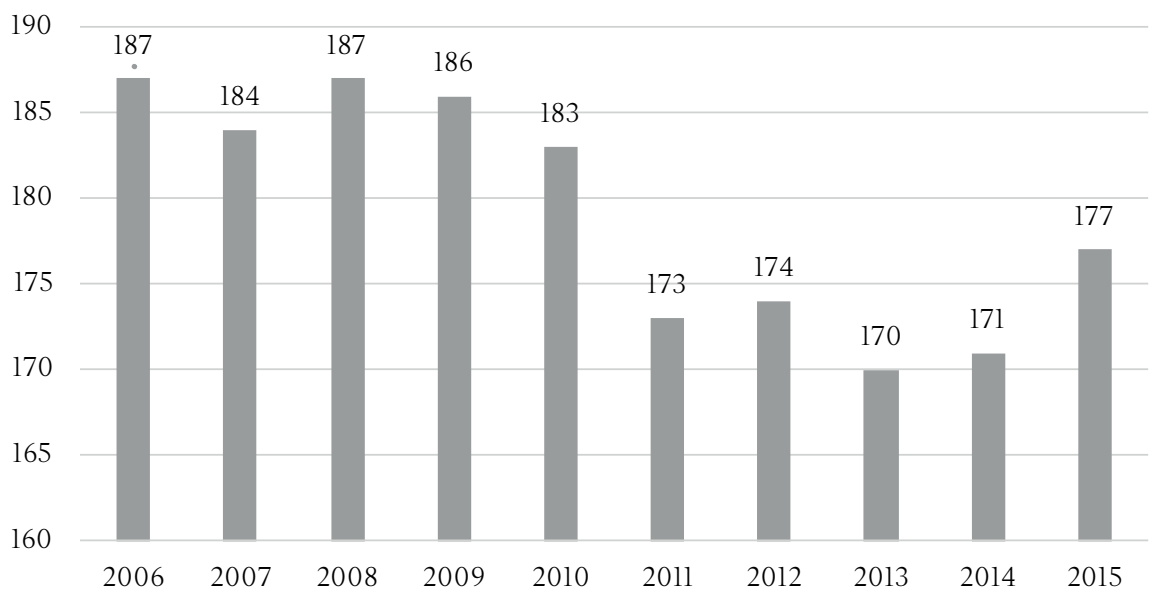

Source: Own preparation based on Local Data Bank (2017).

\section{Chart 2.}

The share of own revenue in the total revenue of cultural institutions (in \%)

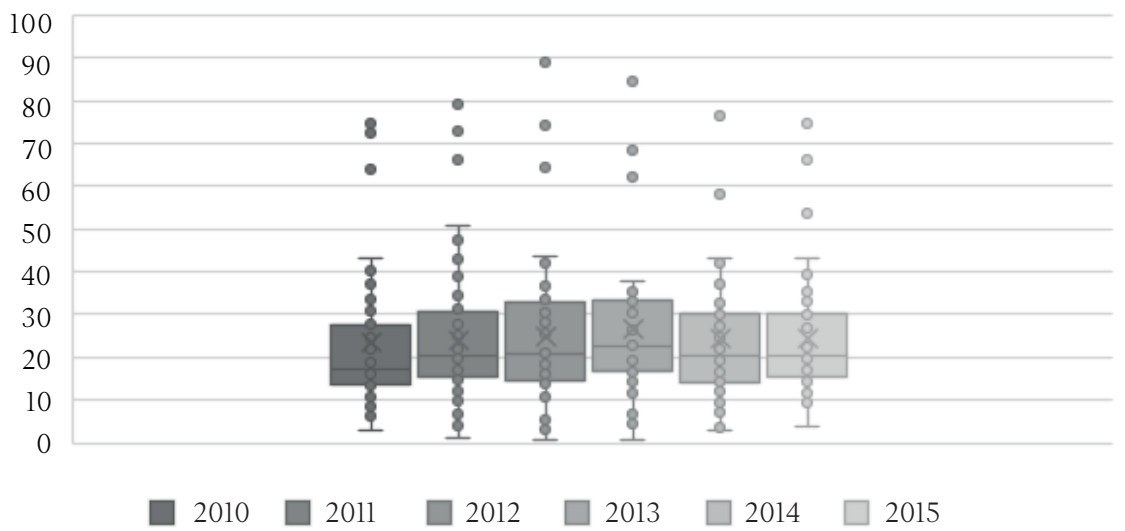

Source: Own preparation based on reports on the implementation of financial plans of municipal cultural institutions of the cities: Białystok (2010-2015), Bielsko-Biała (2010-2015), Bydgoszcz (2010-2015), Bytom (2010-2015), Częstochowa (2010-2015), Gdańsk (2010-2015), Gdynia (2010-2015), Katowice (2010-2015), Kraków (2010-2015), Lublin (2010-2015), Łódź (2010 2015), Olsztyn (2010-2015), Poznań (2010-2015), Radom (2010-2015), Szczecin (2010-2015), Toruń (2010-2015), Tychy (2010-2015), Warszawa (2010-2015), Wrocław (2010-2015). 


\section{Chart 3.}

The share of the statutory subsidies in the total revenue of the respective cultural institutions (in \%)

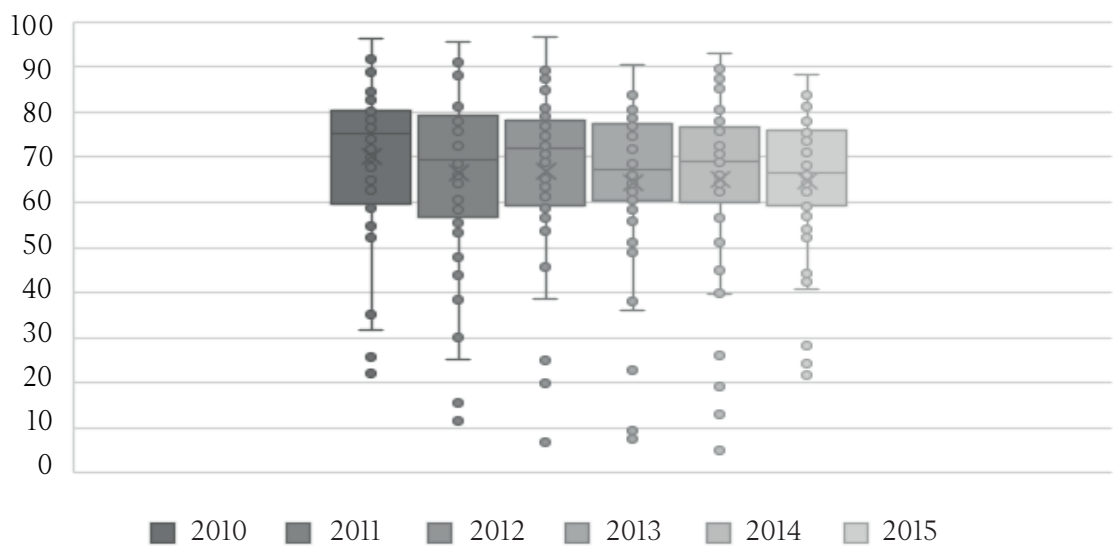

Source: Own preparation based on reports on the implementation of financial plans of municipal cultural institutions of the cities: Białystok (2010-2015), Bielsko-Biała (2010-2015), Bydgoszcz (2010-2015), Bytom (2010-2015), Częstochowa (2010-2015), Gdańsk (2010-2015), Gdynia (2010-2015), Katowice (2010-2015), Kraków (2010-2015), Lublin (2010-2015), Łódź (2010 2015), Olsztyn (2010-2015), Poznań (2010-2015), Radom (2010-2015), Szczecin (2010-2015), Toruń (2010-2015), Tychy (2010-2015), Warszawa (2010-2015), Wrocław (2010-2015).

\section{Chart 4.}

The share of the statutory subsidies in the total costs of the respective cultural institutions (in \%)

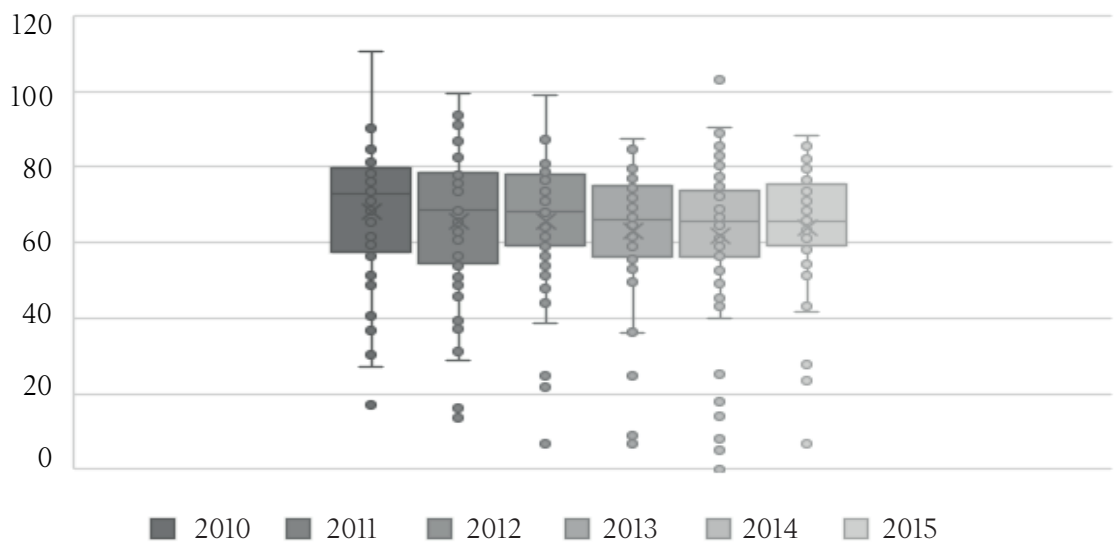

Source: Own preparation based on reports on the implementation of financial plans of municipal cultural institutions of the cities: Białystok (2010-2015), Bielsko-Biała (2010-2015), Bydgoszcz (2010-2015), Bytom (2010-2015), Częstochowa (2010-2015), Gdańsk (2010-2015), Gdynia (2010-2015), Katowice (2010-2015), Kraków (2010-2015), Lublin (2010-2015), 
Łódź (2010-2015), Olsztyn (2010-2015), Poznań (2010-2015), Radom (2010-2015), Szczecin (2010-2015), Toruń (2010-2015), Tychy (2010-2015), Warszawa (2010-2015), Wrocław (2010-2015).

\section{Chart 5.}

Distribution of the financial result as \% of the total costs of the respective cultural institutions between 2010 and 2015

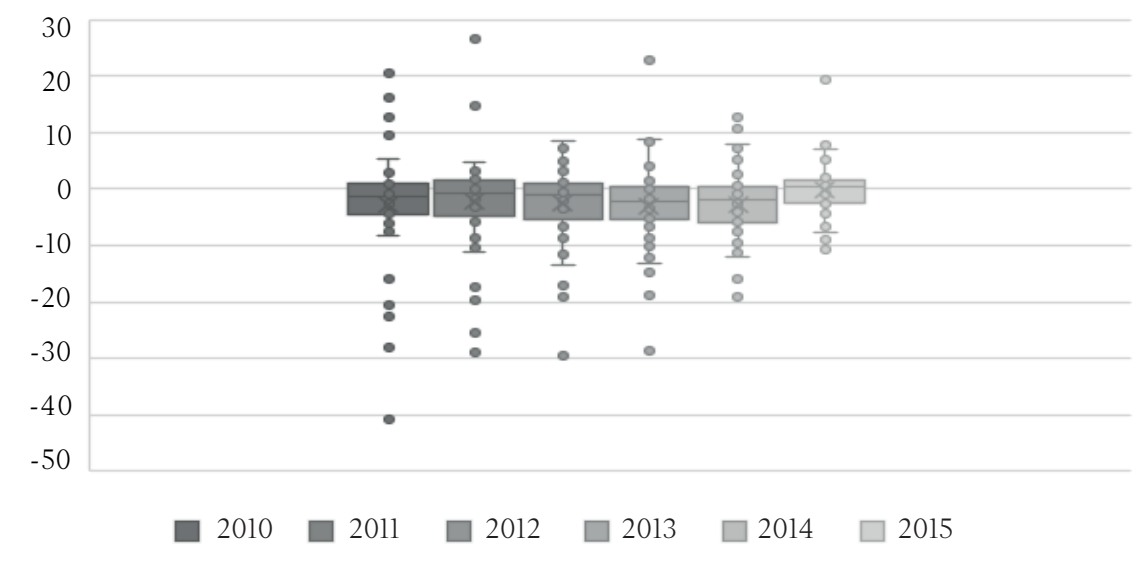

Source: Own preparation based on reports on the implementation of financial plans of municipal cultural institutions of the cities: Białystok (2010-2015), Bielsko-Biała (2010-2015), Bydgoszcz (2010-2015), Bytom (2010-2015), Częstochowa (2010-2015), Gdańsk (2010-2015), Gdynia (2010-2015), Katowice (2010-2015), Kraków (2010-2015), Lublin (2010-2015), Łódź (20102015), Olsztyn (2010 - 2015), Poznań (2010-2015), Radom (2010-2015), Szczecin (2010-2015), Toruń (2010-2015), Tychy (2010-2015), Warszawa (2010-2015), Wrocław (2010-2015). 
